\title{
ANALISIS NILAI TAMBAH USAHA KOPI ARABIKA “ARGOPURO COFFEE" PADA KELOMPOK MASYARAKAT (POKMAS) WALIDA DI DESA TLOGOSARI KECAMATAN SUMBERMALANG
}

\author{
Yudi Hariyanto'), Martono Achmar ${ }^{2 *}$ ) \\ Fakultas Pertanian, Universitas Abdurachman Saleh Situbondo \\ *Email Korespondensi : martono_achmar@unars.ac.id
}

\begin{abstract}
ABSTRAK
Tujuan penelitian adalah untuk mengetahui karakteristik usaha kopi arabika (Dari segi awal tumbuh usaha, proses produksi, teknologi, tenaga kerja, permodalan dan pemasaran) dan menganalisis besarnya nilai tambah yang diperoleh pada usaha kopi arabika pada Pokmas Walida di Desa Tlogosari Kecamatan Sumbermalang. Metode atau analisis data yang digunakan deskriptif dan hayami. Hasil penelitian menunjukkan bahwa karakteristik usaha kopi arabika pada Pokmas Walida: 1). Awal tumbuh usaha meliputi tumbuh karena rasa sosial untuk membantu pekebun dan berdiri pada tahun 2015, 2). Proses produksi meliputi bahan baku dibeli langsung dari petani dan diolah menjadi kopi berbentuk greenbeans, 3). Teknologi pengolahan kopi arabika masih tradisional, 4). Tenaga kerja berjumlah 10 orang yang diambil dari masyarakat sekitar dan upah Rp. 50.000,-/hari, 5). Permodalan merupakan modal sendiri atau swadaya, 6). Pemasaran meliputi penjualan kopi arabika 90\% secara online, 10\% untuk cafe di Situbondo dan daerah pemasaran adalah Jawa Timur sampai Jawa Barat. Sedangkan nilai tambah yang diperoleh pengusaha sebesar Rp 14.920,- per kg, keuntungan sebesar Rp 9.920,- per kg.
\end{abstract}

Kata Kunci : Nilai Tambah, Kopi Arabika, Pokmas Walida

\begin{abstract}
The aim of this study is to determine the characteristics of arabica coffee business (in terms of the beginning of the business, production processes, technology, labor, capital and marketing) and to analyze the amount of added value obtained in the Arabica coffee business at Walida community in Tlogosari Village, Sumbermalang Subdistrict. The method or data analysis used in this study is descriptive analysis. The results showed some characteristics of the arabica coffee business in the Walida Society: 1). The business started in 2015 and grow well because of solidarity to farmers, 2). The production process includes raw materials purchased directly from farmers and processed into coffee in the form of greenbeans, 3$)$. The technology of arabica coffee processing is still done in traditional ways, 4). A total of 10 workers were taken from the society and their wage is Rp. 50.000, - / day, 5). The capital is self-capital or self-help, 6). Marketing includes the sale of $90 \%$ arabica coffee online, $10 \%$ for cafes in Situbondo and the marketing area is East Java to West Java. As an addition, the added value obtained by entrepreneur is Rp. 14,920 per $\mathrm{kg}$, and the profit is Rp. 9,920 per $\mathrm{kg}$.
\end{abstract} Keywords: Added Value, Arabica Coffee, Walida community, Sumbermalang

\section{PENDAHULUAN}

Pertanian merupakan salah satu sektor yang berororientasi ekspor terutama sub sektor perkebunannya. Peran sub sektor perkebunan sebagai penghasil devisa tidak diragukan lagi. Dibandingkan sektor non migas lainnya sub sektor perkebunan memiliki keunggulan komparatif yaitu tersedianya lahan yang belum dimanfaatkan secara optimal, lokasi yang berada di kawasan dengan iklim yang menunjang serta tersedianya tenaga 
kerja yang cukup melimpah yang semuanya merupakan potensi yang dapat dimanfaatkan untuk memperkuat daya saing harga produk-produk perkebunan Indonesia di pasar dunia (Utami, 2012). Komoditi strategis perkebunan di Indonesia adalah kelapa sawit, karet, kopi, teh dan lada.

Kopi menjadi salah satu komoditas unggulan dalam sektor perkebunan Indonesia. Hal tersebut dibuktikan dengan Keputusan Menteri Pertanian nomor 511/Kpts/PD.310/9/ 2006 tentang jenis komoditas tanaman binaan Direktorat Jenderal Perkebunan, Direktorat Jenderal Tanaman Pangan dan Direktorat Jenderal Hortikultura yang menjadikan kopi sebagai salah satu komoditas unggulan. Peran komoditas kopi bagi perekonomian Indonesia cukup penting, baik sebagai sumber pendapatan bagi petani kopi, sumber devisa, penghasil bahan baku industri, maupun penyedia lapangan kerja melalui kegiatan pengolahan, pemasaran, dan perdagangan (ekspor dan impor) (Anonim, 2015).

Wilayah di Kabupaten Situbondo yang memiliki potensi besar untuk mengembangkan perkebunan kopi arabika adalah Kecamatan Arjasa. Namun saat ini terdapat juga wilayah yang berpotensi dalam pengembangan perkebunan kopi yaitu pada Wilayah Situbondo bagian barat, lebih tepatnya daerah Kecamatan Sumbermalang yang memiliki topografi dataran tinggi juga sangat bagus untuk pengembangan tanaman kopi dan sampai saat ini sudah mulai banyak perkebunan tanaman kopi yang ada serta sudah ada pengolahan tanaman kopi jenis arabika yang beroperasi disana dan salah satunya usaha pengolahan produk kopi arabika pada kelompok masyarakat tani Pokmas Walida.

Pokmas Walida Kecamatan Sumbermalang berfungsi sebagai tempat partisipasi masyarakat dalam setiap proses dan usaha peningkatan produksi agribisnis kopi. Sedangkan untuk masyarakat disekitar kelompok tani dapat dijadikan sebagai sumber informasi dalam usaha pengelolaan lahan usahatani kopi, serta sebagai basis pembelajaran masyarakat dalam usaha peningkatan produksi dan pendapatan dengan tetap memperhatikan kelestarian sumberdaya lahan usahatani. Dengan demikian usahatani kopi akan menjadi meningkat yang akhirnya akan memberikan peningkatan pendapatan dan kesejahteraan masyarakat petani, khususnya petani kopi.

Sebelum adanya Pokmas Walida, permasalahan yang banyak muncul pada petani kopi di Kecamatan Sumbermalang adalah keterbatasan pengetahuan akan aspek pengolahan hasil pertanian sehingga seringkali hasil buah kopi langsung dijual karena mereka ingin mendapatkan uang kontan untuk keperluan yang mendesak. Karena kebutuhan yang mendesak ini, maka kegiatan panen yang mereka lakukan juga menjadi kurang sempurna dan akibatnya nilai tambah hasil pertanian tersebut menjadi rendah. Hal inilah yang mendasari dibentuknya kelompok masyarakat tani Walida (Pokmas Walida) untuk membuat industri hilir dari buah kopi cerry menjadi kopi greenbeans. Kelompok ini mengolah dari buah kopi cerry menjadi kopi biji mentah greenbeans siap sangrai dengan ciri khas wangi pisang yang siap diolah menjadi kopi bubuk siap konsumsi. Hal ini dilakukan dengan tujuan untuk meningkatkan nilai tambah. Kopi diperoleh dari Anggota kelompok yang bertujuan untuk meningkatkan dan mensejahterakat taraf hidup petani kopi dari kelompok maupun petani sekitar.

Perkembangan usaha pengolahan kopi arabika Pokmas Walida dari waktu ke waktu mengalami peningkatan yang cukup pesat, hal ini peneliti ketahui berdasarkan survey awal terhadap pengusaha Pokmas Walida yang mengatakan bahwa produksi yang dilakukan dari awal sampai sekarang sudah semakin meningkat, pasar kopi arabika masih tinggi sehingga permintaan akan produk kopi arabika terus naik sehingga makin tingginya produksi dan pemasaran yang dilakukan. Apalagi untuk saat-saat ini produk kopi arabika greenbeans Pokmas Walida Kecamatan Sumbermalang sudah cukup banyak dikenal masyarakat lokal, luar kota bahkan sampai luar pulau sehingga prospek usaha produk kopi arabika juga ikut meningkat. 
Berdasarkan latar belakang di atas, maka dilakukan penelitian dengan judul Analisis Nilai Tambah Usaha Kopi Arabika "Argopuro Coffee" Pada Kelompok Masyarakat (Pokmas) Walida Di Desa Tlogosari Kecamatan Sumbermalang Kabupaten Situbondo. berikut:

Berdasarkan latar belakang diatas maka ditetapkan rumusan masalah sebagai

a. Bagaimana karakteristik usaha kopi arabika (Dari segi awal tumbuh usaha, proses produksi dan teknologi, tenaga kerja, permodalan dan pemasaran) pada Pokmas Walida di Desa Tlogosari Kecamatan Sumbermalang?

b. Bagaimana nilai tambah yang diperoleh pada usaha pengolahan kopi arabika pada Pokmas Walida di Desa Tlogosari Kecamatan Sumbermalang?

\section{METODE PENELITIAN}

\section{Tempat dan Waktu Penelitian}

Penentuan daerah penelitian dilakukan secara sengaja (Purposive Method) pada Pokmas Walida di Desa Tlogosari Kecamatan Sumbermalang Kabupaten Situbondo. Lokasi ini dipilih atas pertimbangan sebagai berikut :

1. Kecamatan Sumbermalang merupakan salah satu wilayah di Kabupaten Situbondo yang memiliki usaha produksi kopi arabika dan masih berjalan secara intensif.

2. Kecamatan Sumbermalang memiliki kelompok masyarakat yaitu Pokmas Walida yang melakukan pengolahan kopi arabika hasil usahataninya sendiri.

3. Pokmas Walida merupakan satu-satunya kelompok yang menjual sendiri hasil usahatani kopinya dalam bentuk kemasan kopi greenbeans.

Penelitian dilaksanakan pada bulan Oktober 2017 sampai bulan Desember 2017.

\section{Populasi dan Sampel}

Populasi dalam peneltian ini adalah pengusaha pengolahan kopi arabika pada Pokmas Walida Desa Tlogosari Kecamatan Sumbermalang, maka penarikan sampel dalam penelitian ini menggunakan metode studi kasus. Studi kasus merupakan deskripsi mengenai suatu pengalaman dalam kehidupan nyata yang digunakan untuk menetapkan poin - poin penting (Sugiyono, 2015). Jumlah sampel yang diambil sebanyak satu yakni pengusaha pengolahan kopi arabika pada Pokmas Walida Desa Tlogosari Kecamatan Sumbermalang.

\section{Teknik Pengumpulan Data}

Berdasarkan jenis data yang dikumpulkan dalam penelitian ini dibedakan menjadi dua kelompok yaitu data primer dan data sekunder. Teknik Pengumpulan data dalam penelitian ini dilakukan denga cara sebagai berikut :

1. Kuesioner adalah suatu cara pengumpulan data dengan cara memberikan daftar pertanyaan yang telah disediakan.

2. Wawancara adalah proses memperoleh data dengan cara tanya jawab secara langsung dengan pengusaha.

3. Observasi adalah pengamatan langsung pada objek yang akan diteliti .

\section{Teknik Analisis Data}

Hipotesa pertama yaitu mengetahui karakteristik usaha kopi arabika (dari segi awal tumbuh usaha, proses produksi, teknologi, tenaga kerja, permodalan dan pemasaran) pada Pokmas Walida di Kecamatan Sumbermalang diperoleh dengan analisis deskriptif.

Hipotesa kedua yaitu mengetahui bagaimana nilai tambah yang diperoleh pada usaha pengolahan kopi arabika pada Pokmas Walida di Kecamatan Sumbermalang 
dianalisis dengan metode hayami. Adapun prosedur perhitungan nilai tambah dengan menggunakan metode hayami dapat disajikan dalam bentuk tabel sebagai berikut:

Tabel 1. Perhitungan Nilai Tambah

\begin{tabular}{|c|c|}
\hline Variabel & Nilai \\
\hline \multicolumn{2}{|l|}{ Output, Input dan Harga } \\
\hline 1. Output (Kg/Siklus) & A \\
\hline 2. Bahan baku (Kg/ Siklus) & B \\
\hline 3. Tenaga kerja (HKP/Hari) & $\mathrm{C}$ \\
\hline 4. $\quad$ Faktor konversi $(1: 2)$ & $\mathrm{D}=\mathrm{A} / \mathrm{B}$ \\
\hline 5. Koefisien tenaga kerja (3:2) & $E=C / B$ \\
\hline 6. Harga output $(\mathrm{Rp} / \mathrm{Kg})$ & $\mathrm{F}$ \\
\hline Upah rata-rata tenaga kerja (Rp/HKP) & G \\
\hline \multicolumn{2}{|l|}{ Pendapatan dan Keuntungan (Rp/Kg) } \\
\hline 8. Harga bahan baku(Rp/Kg) & $\mathrm{H}$ \\
\hline 9. Harga input lain $(\mathrm{Rp} / \mathrm{Kg})$ & I \\
\hline 10. Nilai output $(4 \times 6)$ & $J=D \times F$ \\
\hline 11. a. Nilai tambah $(10-8-9)$ & $\mathrm{K}=\mathrm{J}-\mathrm{H}-\mathrm{I}$ \\
\hline b. Rasio nilai tambah [(11a:10)×100\%] & $\mathrm{L} \%=\mathrm{K} / \mathrm{J} \times 100 \%$ \\
\hline 12. a. Imbalan tenaga kerja $(5 \times 7)$ & $M=E \times G$ \\
\hline b. Bagian tenaga kerja [(12a:11a)×100\%] & $\mathrm{N} \%=\mathrm{M} / \mathrm{K} \times 100 \%$ \\
\hline 13. a. Keuntungan $(11 a-12 a)$ & $\mathrm{O}=\mathrm{K}-\mathrm{M}$ \\
\hline b. Tingkat keuntungan [(13a:10)×100\%] & $\mathrm{P} \%=0 / \mathrm{J} \times 100 \%$ \\
\hline \multicolumn{2}{|l|}{ Balas Jasa Pemilik Faktor Produksi } \\
\hline 14. Marjin (10-8) & $\mathrm{Q}=\mathrm{J}-\mathrm{H}$ \\
\hline a. Pendapatan tenaga kerja & $\mathrm{R} \%=\mathrm{M} / \mathrm{Q} \times 100 \%$ \\
\hline b. Sumbangan input lain & $\mathrm{S} \%=\mathrm{I} / \mathrm{Q} \times 100 \%$ \\
\hline c. Keuntungan perusahaan & $\mathrm{T} \%=0 / \mathrm{Q} \times 100 \%$ \\
\hline
\end{tabular}

Sumber: Hayami, 1987

\section{HASIL DAN PEMBAHASAN}

\section{Karakteristik Usaha Kopi Arabika Pada Pokmas Walida}

1. Aspek Awal Tumbuh Usaha Kopi Arabika

Kegiatan agroindustri kopi arabika Pokmas Walida ini tergolong industri kecil berbasis perkebunan khususnya tanaman kopi yang tidak hanya memberikan kesempatan berusaha, akan tetapi juga membuka peluang kesempatan kerja bagi masyarakat disekitarnya. Hasil pengamatan di lapang menunjukkan bahwa Agroindustri kopi arabika Pokmas Walida ada beberapa hal yang menjadi alasan pemilihan dalam proses tumbuhnya usaha, antara lain: (1) tumbuh berdasarkan keinginan yang kuat dalam berusaha dan kepemilikan modal yang cukup dalam keluarga; (2) tumbuh atas dasar pengamatan pengusaha terhadap produk kopi yang berlimpah; dan (3) tumbuh atas dasar keinginan rasa sosial yang tinggi untuk membantu dalam membeli hasil produk usahatani kopi yang dijalankan pekebun.

Dari berbagai alasan proses tumbuhnya usaha agroindustri kopi arabika Pokmas Walida, ternyata yang utama adalah tumbuh atas dasar keinginan rasa sosial yang tinggi untuk membantu dalam membeli hasil produk usahatani kopi yang dijalankan pekebun di daerah Sumbermalang. Agroindustri ini dikelola oleh Bapak Ahmad Muhlisin. Bapak Ahmad Muhlisin mendirikan agroindustri kopi arabika berbentuk biji mentah yang biasa disebut greenbeans karena melihat potensi kopi arabika yang melimpah di Kabupaten Situbondo khususnya Kecamatan Sumbermalang. Awal mula berdiri agroindustri ini pada tahun 2015 dimana pada saat itu Bapak Ahmad Muhlisin mencoba melihat kondisi potensi kopi arabika di daerah Sumbermalang yang sangat melimpah. Selang beberapa bulan 
kemudian ada keinginan untuk berusaha dalam pengolahan pasca panen kopi yaitu dengan cara mengolah buah kopi cerry yang dihasilkan pekebun menjadi biji kopi mentah greenbeans siap sangrai dan diolah bubuk kopi dengan rasa dan wangi yang khas berbau pisang.

\section{Aspek Proses Produksi dan Teknologi}

Pengusaha agroindustri kopi arabika greenbeans Pokmas Walida membeli bahan baku kopi langsung kepada pekebun di daerah Sumbermalang. Kopi yang dibeli pengusaha ini berbentuk kopi buah berbentuk cerry. Kopi yang dibeli ini berasal dari pekebun kopi yang hanya memiliki kebun kopi di daerah Sumbermalang, karena kualitas kopi yang dihasilkan oleh pekebun disana sangat baik. Hasil kopi yang ditanam pada daerah perkebunan rakyat daerah Sumbermalang memiliki hasil yang khas yaitu memiliki rasa dan wangi pisang bila dirasakan. Hal inilah yang membuat pengusaha agroindustri kopi arabika greenbeans Pokmas Walida memberikan kepercayaan kepada para pekebun tersebut untuk dapat memastikan bahwa buah kopi cerry yang dihasilkan benar-benar memiliki kualitas yang baik.

Untuk agroindustri kopi arabika greenbeans Pokmas Walida, pemilihan komoditas buah kopi arabika harus dilakukan secara selektif. Bahan baku kopi yang diinginkan antara lain: (1) kopi berukuran $6 \mathrm{~mm}$; (2) biji kopi tidak cacat; dan (3) kopi yang dibeli harus benar-benar berasal dari buah merah. Komoditas kopi yang tersedia di wilayah Kecamatan Sumbermalang, tidak hanya dimanfaatkan dan dibeli oleh pengusaha Pokmas Walida tetapi juga dimanfaatkan dan dibeli oleh tengkulak dari luar Kecamatan Sumbermalang, sehingga pengusaha bersaing untuk memperoleh bahan baku sesuai dengan kebutuhannya.

Pengusaha ini berupaya membeli bahan baku dalam jumlah relatif lebih banyak pada saat musim panen, karena pada saat musim panen produk kopi sangat melimpah dan harganya relatif lebih murah. Pembelian ini untuk mengkompensasi pembelian yang relatif sedikit diluar musim panen atau pada waktu pasokan di pasar menipis. Proses pembelian bahan baku utama bagi agroindustri kopi arabika Pokmas Walida dilakukan dengan cara tidak tunai dengan mendatangi langsung lokasi bahan baku dan melakukan pemesanan, sistem pembayaran dengan uang di muka sebagai kata jadi dan pelunasan setelah bahan diterima pengusaha. Pada awalnya agroindustri kopi arabika greenbeans Pokmas Walida proses pembelian bahan baku kopi biasanya dilakukan secara tunai datang langsung kepada pekebun untuk melihat kualitas kopi yang nantinya dapat diolah menjadi kopi arabika greenbeans. Namun pada saat ini pengusaha sudah mempercayai kepada para pekebun daerah Sumbermalang yang sudah menjadi pemasok buah kopi cerry pada agroindustrinya.

Pada Pokmas Walida produksi dari awal berdiri sejak tahun 2015 sampai sekarang sudah mulai mengalami peningkatan. Data produksi kopi arabika Pokmas Walida dapat diuraikan sebagai berikut:

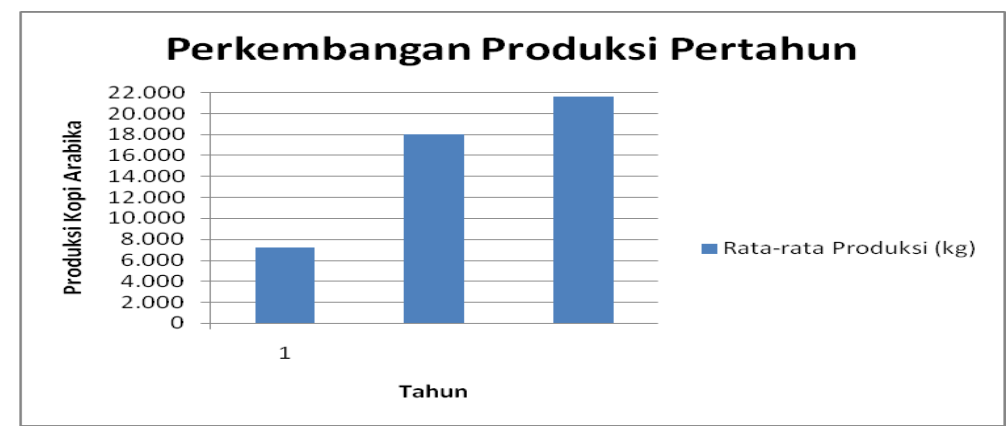

Gambar 1. Perkembangan Usaha 
Proses pembuatan kopi arabika greenbeans ini memerlukan waktu sekitar Teknologi yang diterapkan pengusaha agroindustri kopi arabika Pokmas Walida adalah teknologi yang masih dibilang tradisional mengarah ke semi modern. Misalkan saja untuk untuk penjemuran masih menggunakan tahapan secara manual yaitu buah kopi yang sudah merah dijemur pada para-para diterik matahari sampai kering dengan ciri-ciri buah sudah kecoklatan, buah sudah mulai keriput dan kadar air sudah berkurang, pada proses penyortiran untuk memilih buah kopi cerry yang bagus dan tidak busuk masih menggunakan sistem manual, begitu juga dengan penyortiran biji kopi yang baik tanpa ada cacat maupun patah masih menggunakan manual dengan tenaga manusia dan hanya pemisahan biji kopi dengan daging buah kopi saja yang sudah menggunakan mesin huller.

Proses pembuatan kopi arabika greenbeans yang dilakukan agroindustri kopi arabika Pokmas Walida masih dibilang cukup memerlukan waktu agak lama dalam proses produksinya, karena masih banyak menggunakan teknologi tradisional dan manual. 1 hari dalam sekali proses produksi. Dalam waktu sehari bahan baku yang diolah bisa mencapai rata-rata $100 \mathrm{~kg}$ atau menghasilkan sekitar $60 \mathrm{~kg}$ biji kopi arabika mentah greenbeans setiap hari. Proses pengolahan kopi arabika greenbeans dilakukan pengusaha hampir setiap hari untuk mengisi kekosongan stok penjualan.

\section{Aspek Tenaga Kerja}

Dari hasil pengamatan dan wawancara dengan pengusaha agroindustri kopi arabika greenbeans Pokmas Walida mengungkapkan bahwa agroindustri saat ini perlu dikembangkan dan dipertahankan, dikarenakan ada beberapa manfaat yang bisa diperoleh dari agroindustri tersebut. Salah satunya yaitu adanya penyerapan tenaga kerja dan sebagai sumber pendapatan bagi keluarga dari tenaga kerja tersebut. Keberadaan agoindustri yang dijalankan tidak terlepas dari peranan rumah tangga pengusaha dan tenaga kerja sebagai bagian yang terpenting dalam proses produksinya. Selain itu harapan dari berdirinya agroindustri ini dapat meningkatkan penyerapan tenaga kerja dan meningkatkan pendapatan untuk kemudian dapat dialokasikan terhadap pengeluaran rumah tangganya.

Tenaga kerja yang terampil diperlukan oleh agroindustri walaupun pengusaha Agroindustri Kopi Arabika Pokmas Walida menyatakan tidak mensyaratkan adanya keahlian khusus dari tenaga kerja yang digunakan dalam proses produksi. Kebutuhan tenaga kerja juga tidak sulit didapatkan oleh pengusaha Agroindustri Kopi Arabika Pokmas Walida. Mayoritas tenaga kerja yang digunakan berasal dari wilayah sekitar lokasi agroindustri mereka atau tetangga dekat. Hal inilah yang membuat pengusaha tidak terlalu menjadikan kendala atau hambatan dalam memperoleh tenaga kerja.

Kebutuhan tenaga kerja pada agroindustri kopi arabika greenbeans berbentuk biji mentah Pokmas Walida tidak terlalu banyak. Tenaga kerja yang dimiliki oleh pengusaha aroindustri ini hanya 10 orang tenaga kerja yang berasal dari luar keluarga dan 1 orang berasal dari dalam keluarga. Tenaga kerja pada agorindustri ini terdiri dari sepuluh (10) orang pria. Dari masing-masing tenaga kerja ini memiliki spesialisasi yang berbeda-beda. Mulai dari proses penjemuran sampai pengemasan.

Seperti halnya agroindustri lainnya agroindustri kopi arabika biji mentah greenbeans Pokmas Walida juga menerapkan penerapan jam kerja. Penerapan jam kerja pada tenaga kerja yakni dimulai pada pukul 07.00 WIB hingga pukul 16.00 WIB dengan sistem pengupahan harian, mingguan dan bulanan sesuai permintaan tenaga kerja. Sistem pengupahan tidak diberlakukan pada tenaga kerja yang digunakan berasal dari tenaga kerja dalam keluarga. Upah yang diberikan untuk 
tenaga kerja pada agroindustri kopi arabika greenbeans Pokmas Walida sama yaitu keseluruhan tenaga kerja memperoleh upah sebesar Rp. 50.000,- perhari

\section{Aspek Permodalan}

Sampai saat ini di Kecamatan Sumbermalang, pengusaha agroindustri kopi arabika berbentuk biji mentah greenbeans Pokmas Walida beranggapan bahwa agroindustri yang bergerak di bidang pertanian masih didominasi oleh usaha skala industri rumah tangga dan industri kecil namun telah bersifat komersial. Karena telah bersifat komersial, maka salah satu tujuan dalam pengelolaan agroindustri adalah untuk memperoleh keuntungan. Oleh karena itu, pengusaha akan mengalokasikan sumberdaya yang dimiliki sesuai dengan tujuan yang akan dicapai.

Biaya produksi yang dikeluarkan oleh pengusaha agroindustri kopi arabika greenbeans setiap harinya sangat besar. Oleh karena itu pengusaha mengeluarkan modal dalam pembelian bahan baku buah kopi cerry sangat besar. Modal merupakan salah satu diantara faktor produksi yang dianggap perlu bagi sebuah kesatuan produksi atau usaha. Modal usaha yang di miliki pengusaha ini digunakan untuk pembelian bahan-bahan baku produksi seperti buah kopi cerry dan untuk membayar upah tenaga kerja tiap harinya. Selain itu juga modal digunakan untuk pengadaan peralatan yang digunakan untuk memproduksi kopi arabika greenbeans. Permodalan usaha dapat menunjukkan kepada kekayaan finansial, terutama dalam penggunaan awal atau menjaga kelanjutan usaha.

Pada Pokmas Walida permodalan usaha didapat dari modal sendiri sejak awal berdiri tahun 2015 sampai sekarang untuk menghasilkan produksi yang dijalankan Data permodalan usaha kopi arabika Pokmas Walida setiap tahunnya dapat diuraikan sebagai berikut:

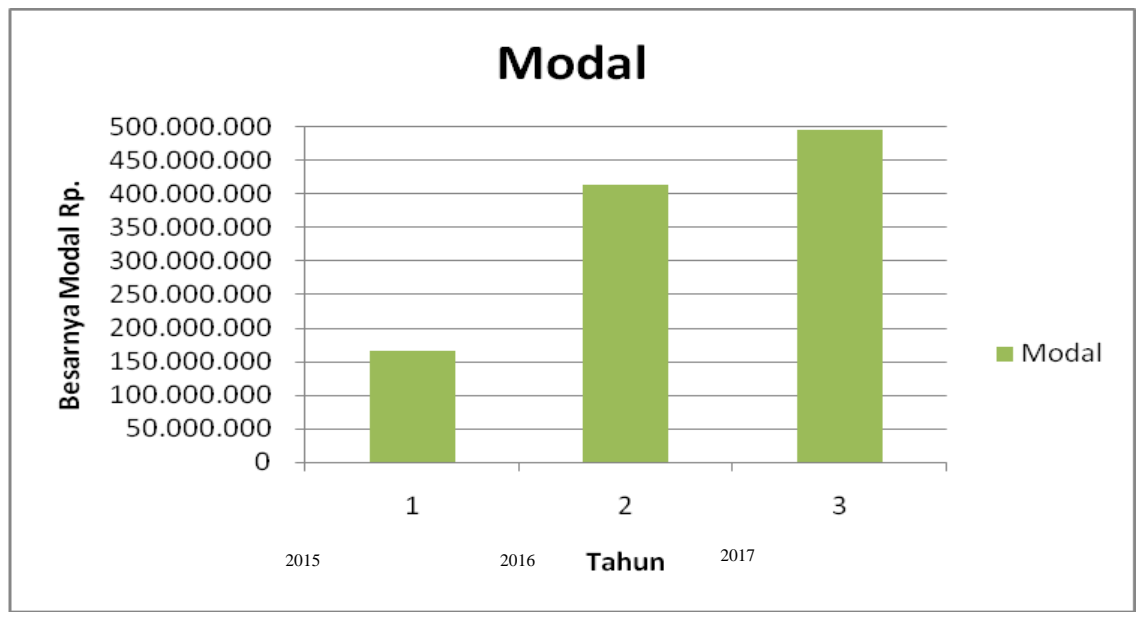

Gambar 2. Perkembangan Modal

Menurut informasi yang didapat menyatakan bahwa pengusaha agroindustri kopi arabika greenbeans Pokmas Walida selama ini masih menggunakan modal sendiri dan tidak pernah menerima bantuan modal dari pemerintah atau instansi perbankan. Pengusaha ini menganggap peran pemerintah ataupun peran perbankan untuk membantu industri berbasis rumah tangga maupun industri kecil masih kurang. Selain itu pelaku industri menginginkan jika misalkan meminjam bantuan modal dari perbankan tidak ingin diberatkan oleh biaya-biaya seperti bunga dan 
biaya administrasi. Jika bunga dan biaya administrasi terlalu besar tentunya akan sangat memberatkan pelaku usaha di Kabupaten Situbondo ini.

5. Aspek Pemasaran Produk

Pada pemasaran kopi arabika Pokmas Walida digunakan sistem 4P untuk memasarkan produknya, antara lain:

a. Aspek produk

Kualitas produk kopi arabika yang selalu dijaga oleh pengusaha Pokmas Walida adalah rasa dan wangi pisang yang memang menjadi ciri khas dari kopi arabika greenbeans. Untuk memperoleh kualitas dan mutu produk kopi yang baik ditinjau dari segala aspek seperti kualitas dan mutu bahan baku kopi dari pekebun harus bagus karena bahan baku kopi yang kualitasnya jelek akan menghasilkan produk kopi bubuk yang kurang diminati para penikmat kopi, mutu sumber daya manusia (tenaga kerja) yang mampu bekerja secara efisien

b. Aspek harga

Dari segi harga, kopi arabika yang ditawarkan kepada konsumen senilai $\mathrm{Rp}$. 75.000,-/kg kopi arabika greenbeans. Harga tersebut dinilai layak dan sepadan dengan kualitas produk yang ditawarkan sehingga harga produk tersebut bisa dibilang bisa bersaing dengan harga produk lainnya yang sama-sama menjual produk kopi arabika sejenis.

c. Aspek lokasi/distribusi

Dari segi lokasi/distribusi, Pokmas Walida sudah tepat memilih lokasi produksi di Kecamatan Sumbermalang karena Kecamatan Sumbermalang merupakan salah satu sentra perkebunan kopi rakyat yang ada di Dearah Situbondo sehingga ketersediaan dan kebutuhan akan bahan baku mudah terpenuhi dbagi pengusaha. Dari segi distribusi, Pokmas Walida sudah menetapkan mutu pelayanan yang baik yaitu mutu distribusi yang mampu menyerahkan produk sesuai dengan waktu yang dikehendaki.

\section{d. Aspek promosi}

Dari segi promosi, Pokmas Walida melakukan promosi kebanyakan melalui sistem online sebab sistem tersebut dirasa efektif dalam mengenalkan produk kopi arabika yang diproduksi Pokmas Walida.

Produk kopi arabika greenbeans yang dihasilkan agroindustri ini banyak tersebar di seluruh kota-kota besar mulai dari Jawa Timur sampai Jawa Barat. Sistem pemasaran yang dilakukan oleh pengusaha yaitu dengan cara memasarkan melalui internet dan website. Hampir 90\% produk kopi arabika biji mentah greenbeans dipasarkan secara online dan sisanya hanya $10 \%$ yang dipasarkan diwilayah Situbondo kepada cafe-cafe yang memang sudah kenal dan langganan dengan Pokmas Walida, sehingga untuk pangsa pasar kopi arabika yang paling utama adalah cafe maupun restoran modern yang kebanyakan berada di kota-kota besar di Indonesia. Untuk daerah pemasaran terbesar adalah daerah Jakarta dan Bogor melalui pemesanan online.

Dari hasil analisa deskriptif, pembahasan mengenai karakteristik agroindustri pada Pokmas Walida yang dijadikan sampel penelitian dapat ditarik kesimpulan sebagai berikut: 
Tabel 2. Karakteristik Usaha Kopi Arabika Pokmas Walida

\begin{tabular}{|c|c|}
\hline Karakteristik & Usaha Kopi Arabika Pokmas Walida \\
\hline Pertumbuhan Usaha & $\begin{array}{l}\text { - Tumbuh karena rasa sosial untuk membantu dalam membeli } \\
\text { hasil usahatani yang dijalankan pekebun di daerah } \\
\text { Sumbermalang } \\
\text { - Berdiri pada tahun } 2015\end{array}$ \\
\hline $\begin{array}{l}\text { Proses produksi dan } \\
\text { teknologi }\end{array}$ & $\begin{array}{l}\text { - Bahan baku buah kopi cerry dibeli langsung dari pekebun } \\
\text { kopi di daerah Sumbermalang } \\
\text { - Teknologi pengolahan kopi arabika biji mentah greenbeans } \\
\text { masih tradisional dan manual } \\
\text { - Proses pengolahan kopi arabika biji mentah greenbeans } \\
\text { mudah dilakukan. }\end{array}$ \\
\hline Tenaga kerja & $\begin{array}{l}\text { - Kebutuhan tenaga kerja diperoleh disekitar tempat usaha } \\
\text { - Memerlukan } 10 \text { orang tenaga kerja luar keluarga dan } 1 \text { orang } \\
\text { tenaga kerja dalam keluarga } \\
\text { - Upah sebesar Rp. 50.000,- per hari. }\end{array}$ \\
\hline Permodalan & $\begin{array}{l}\text { - Modal yang dibutuhkan tidak terlalu besar } \\
\text { - Modal yang digunakan bersumber dari modal sendiri } \\
\text { - Belum pernah mendapatkan bantuan modal dari pemerintah } \\
\text { atau instansi perbankan }\end{array}$ \\
\hline Pemasaran & $\begin{array}{l}\text { - Penjualan kopi arabika } 90 \% \text { secara online melalui website } \\
\text { - } 10 \% \text { penjualannya adalah untuk cafe di daerah Situbondo } \\
\text { yang memang sudah langganan. } \\
\text { - Kebanyakan daerah pemasaran adalah kota besar di Jawa } \\
\text { Timur sampai Jawa Barat dan yang paling banyak adalah } \\
\text { daerah Jakarta dan Bogor }\end{array}$ \\
\hline
\end{tabular}

Sumber: Data diolah

\section{Nilai Tambah Pengolahan Kopi Arabika}

Nilai tambah pengolahan kopi arabika di daerah penelitian, dihitung dengan menggunakan model perhitungan hayami. Selain nilai tambah, model perhitungan hayami juga menganalisis pendapatan tenaga kerja, keuntungan pengusaha, serta dapat melihat margin yang diperoleh dari pengolahan kopi arabika tersebut. Secara rinci, perhitungan nilai tambah dengan menggunakan metode hayami berdasarkan data yang diperoleh dari lapangan dilihat pada Tabel berikut:

Tabel 3 Rata-rata Nilai Tambah Pengolahan Kopi Arabika Pokmas Walida Di Kec. Sumbermalang.

\begin{tabular}{lr}
\hline \multicolumn{1}{c}{ Variabel } & Nilai \\
\hline I. Output, Input dan Harga & 60 \\
\hline 1. Output (Kg/Hari) & 100 \\
2. Bahan baku (Kg/Hari) & 10 \\
3. Tenaga kerja (HKP/Hari) & 0,6 \\
4. Faktor konversi (1:2) & 0,1 \\
5. Koefisien tenaga kerja (3:2) & 75.000 \\
6. Harga output (Rp/ Kg) & 50.000 \\
7. Upah rata-rata tenaga kerja (Rp/HKP) & 7.000 \\
\hline II. Pendapatan dan Keuntungan & \\
\hline 1. Harga bahan baku (Rp/ Kg) & \\
2. Harga input lain (Rp/kg)
\end{tabular}


a. Tenaga kerja $\quad 5.000$

b. Biaya penunjang $\quad 1.600$

c. Biaya penyusutan $\quad 16.480$

Total harga input lain $\quad 23.080$

3. Nilai output (Rp/ Kg) $\quad 45.000$

4. a. Nilai tambah (Rp/ Kg) 14.920

$\begin{array}{ll}\text { b. Rasio nilai tambah (\%) 33,16 } & \text { 3. }\end{array}$

5. a. Imbalan tenaga kerja ( $\mathrm{Rp} / \mathrm{Kg}) \quad 5.000$

$\begin{array}{ll}\text { b. Bagian tenaga kerja (\%) } & 33,51\end{array}$

6. a. Keuntungan (Rp/ Kg) $\quad 9.920$

b. Tingkat keuntungan (\%) 22,04

\begin{tabular}{lr}
\hline III.Balas Jasa Pemilik Faktor Produksi & \\
\hline 7. Marjin (Rp/ Kg) & 38.000 \\
a. Pendapatan tenaga kerja (\%) & 13,16 \\
b. Sumbangan input lain (\%) & 60,74 \\
c. Keuntungan perusahaan (\%) & 26,11 \\
\hline
\end{tabular}

Sumber : Data Primer diolah

\section{Imbalan dan Penggunaan Tenaga Kerja}

Tenaga kerja yang digunakan oleh lembaga pemasaran kopi arabika adalah tenaga kerja langsung. Hari kerja dihitung dengan mengkalikan waktu kerja dengan jumlah TK dan dibagi 8. Satu hari kerja yang digunakan adalah 8 jam.

Koefisien tenaga kerja didapat dari hasil pembagian antara nilai input tenaga kerja dengan input bahan baku. Pengusaha kopi arabika greenbeans Pokmas Walida memiliki koefisien tenaga kerja sebesar 0,1 HKP per kg. Artinya pengusaha Kopi Arabika memerlukan waktu 0,8 jam atau 48 menit untuk menghasilkan satu kg kopi arabika. Hal ini menunjukkan bahwa pengusaha kopi arabika Pokmas Walida yang ada di Kecamatan Sumbermalang memerlukan waktu yang cukup cepat untuk menghasilkan satu kg kopi arabika.

Imbalan tenaga kerja diperoleh dari hasil perkalian antara upah rata-rata tenaga kerja per HKP dengan koefisien tenaga kerja. Imbalan ini diberikan atas keseluruhan proses produksi setiap kg kopi arabika dari mulai penjemuran bahan baku sampai pengemasan. Imbalan untuk tenaga kerja pada pengusaha kopi arabika Pokmas Walida sebesar Rp 5.000 per kg atau 33,51\% dari nilai tambah produksi kopi arabika. Artinya setiap Rp 100 per kg nilai tambah akan memberikan pendapatan tenaga kerja sebesar Rp 33,51 per kg.

\section{Distribusi Nilai Tambah}

Distribusi nilai tambah terhadap pendapatan tenaga kerja dan keuntungan dapat dilihat pada tabel. Distribusi nilai tambah terhadap pendapatan tenaga kerja. Imbalan tenaga kerja menunjukkan jumlah pendapatan rata-rata yang diterima tenaga kerja untuk kegiatan produksi setiap satu kg kopi arabika. Imbalan tenaga kerja tergantung dari jumlah hari orang kerja untuk dapat memproduksi satu kg kopi arabika.

Tabel 4. Distribusi Nilai Tambah Terhadap Imbalan Tenaga Kerja dan Keuntungan.

\begin{tabular}{lcr}
\hline \multirow{2}{*}{ Faktor Produksi } & \multicolumn{3}{c}{ Kopi Arabika } \\
\cline { 2 - 4 } & Nilai & \% \\
\hline Imbalan Tenaga Kerja & 5.000 & 33,51 \\
Keuntungan & 9.920 & 22,04 \\
\hline Nilai Tambah & 14.920 & 33,16 \\
\hline Sumber : Data Primer diolah & &
\end{tabular}

Tabel diatas menunjukkan bahwa pendapatan tenaga kerja sebesar Rp 5.000, per kg, jadi bila dikalikan maka pendapatan tenaga kerja dalam sehari yang apabila produksi 
mencapai $60 \mathrm{~kg}$ akan mendapatkan sebesar Rp. 300.000, perhari. Rasio tenaga kerja merupakan persentase dari pendapatan tenaga kerja terhadap nilai tambah. Rasio tenaga kerja pengusaha kopi arabika yaitu sebesar 33,51\% artinya untuk setiap Rp 100,00 dari nilai tambah maka sebesar Rp 33,51 merupakan bagian untuk pendapatan tenaga kerja.

Keuntungan merupakan selisih antara nilai tambah dengan pendapatan tenaga kerja. Keuntungan dari distribusi nilai tambah pengusaha kopi arabika yaitu sebesar Rp. 9.920 per kg, jadi bila dikalikan maka keuntungan pengusaha dalam sehari yang apabila produksi mencapai $60 \mathrm{~kg}$ akan mendapatkan sebesar Rp. 595.200, perhari.

\section{KESIMPULAN}

Berdasarkan hasil penelitian karakteristik dan nilai tambah usaha kopi arabika pada Pokmas Walida di Kecamatan Sumbermalang dapat disimpulkan berikut:

1. Karakteristik usaha kopi arabika pada Pokmas Walida:

a. Awal Tumbuh usaha meliputi tumbuh karena rasa sosial untuk membantu dalam membeli hasil usahatani yang dijalankan pekebun di daerah Sumbermalang dan berdiri pada tahun 2015 .

b. Proses produksi dan teknologi meliputi bahan baku buah kopi cerry dibeli langsung dari pekebun kopi di daerah Sumbermalang, teknologi pengolahan kopi arabika biji mentah greenbeans masih tradisional dan manual dan proses pengolahan kopi arabika biji mentah greenbeans mudah dilakukan.

c. Tenaga kerja meliputi kebutuhan tenaga kerja diperoleh disekitar tempat usaha, memerlukan 10 orang tenaga kerja luar keluarga dan 1 orang tenaga kerja dalam keluarga dan upah sebesar Rp. 50.000,- per hari.

d. Permodalan meliputi modal yang dibutuhkan tidak terlalu besar, modal yang digunakan bersumber dari modal sendiri dan belum pernah mendapatkan bantuan modal dari pemerintah atau instansi perbankan.

e. Pemasaran meliputi penjualan kopi arabika $90 \%$ secara online melalui website, $10 \%$ penjualannya adalah untuk cafe di daerah Situbondo yang memang sudah langganan dan kebanyakan daerah pemasaran adalah kota besar di Jawa Timur sampai Jawa Barat dan yang paling banyak adalah daerah Jakarta dan Bogor.

2. Nilai tambah yang diperoleh pengusaha kopi arabika sebesar Rp 14.920,- per kg kopi arabika, keuntungan pengusaha Rp 9.920,- dan sisanya Rp 5.000 merupakan imbalan tenaga kerja.

\section{REFERENSI}

Anonim. 2015. Rencana Strategis Direktorat Jenderal Perkebunan Tahun 2015-2019. Kementerian Pertanian. Jakarta

Bastara, D. 2016. Strategi Pengembangan Agroindustri Kopi Bubuk Arabika Pada Berbagai Skala Usaha Di Kabupaten Situbondo. Tesis. Program Studi Agribisnis Program Pascasarjanafakultas Pertanian Universitas Jember. Jember

Hayami, Y. T, Kawagoe. Y, Marooka dan M. Siregar. 1987. Agricultural Marketing and Processing in Upland Java, a Perpective FromSunda Village. CEPRT. Bogor.

Najiyati, D. 2008. Budidaya Dan Penanganan Pasca Panen Kopi . Penebar Swadaya. Jakarta

Sugiyono. 2015. Metode Penelitian Kuantitatif, Kualitatif dan $R \&$ D. Alfabeta. Bandung

Utami, Khalida. 2012. Strategi Pengembangan Usaha Tani Kopi Arabica (Coffea Sp) Di Kabupaten Gayu (Studi Kasus : Desa Cane Baru Kecamatan Pantan Cuaca). Jurnal Agribisnis 